\title{
PERTANGGUNGJAWABAN PIDANA PENYIDIK POLRI DALAM KASUS SALAH TANGKAP
}

\author{
Nazaruddin Lathif \\ Fakultas Hukum Universitas Pakuan \\ Jalan Pakuan No. 1 Bogor \\ e-mail : nay.nazar@yahoo.co.id \\ Naskah diterima : 14/10/2018, revisi : 19/10/2018, disetujui \\ $\underline{22 / 10 / 2018}$
}

\begin{abstract}
ABSTRAK
Penangkapan adalah suatu tindakan yang mengurangi atau membatasi kemerdekaan seseorang, maka penangkapan terhadap seseorang harus menjunjung tinggi HAM. HAM yang menjadi dasar setiap orang untuk mendapat perlakuan wajar walaupun seseorang telah melakukan perbuatan tindak pidana, ia harus diperlakukan sebagai pribadi yang tidak bersalah meskipun berdasarkan bukti-bukti yang ada ia bersalah, selama belum ada keputusan pengadilan (Presumption of innocent). Faktor yang mempengaruhi polisi terjebak dalam suatu kesalahan dalam melakukan penangkapan, yaitu dinamika kerja yang begitu kompleks, kurangnya sumber daya manusia Polri dalam menentukan tingkat pelayanan dan penanganan kasus-kasus kejahatan, proses penyidikan yang sangat sulit, target atasan untuk segera menyelesaikan kasus tertentu dalam waktu cepat. Terhadap kekeliruan menangkap orang, polisi harus melakukan pertanggungjawaban yaitu, pertanggungjawaban pidana, perdata, dan administrasi serta disiplin. Upaya penanggulangan agar kasus salah tangkap tidak terjadi lagi yaitu, mengedepankan prinsip demokrasi dan HAM, mengembangkan budaya sipil di Polri, mengefektifkan komisi etika dan disiplin di Polri, mengedepankan fungsi kontrol dari Mabes Polri, peningkatan sumber daya manusia Polri, dan penerapan sanksi pidana yang tegas dalam peraturan perundang-undangan bagi anggota Polri yang melakukan pelanggaran.
\end{abstract}

Kata Kunci: Penangkapan, Penyidik Polri, Pertanggungjawaban Pidana. 


\section{A. Latar Belakang}

Negara Indonesia sebagaimana ditegaskan dalam Pasal 1 ayat (3) Undang-Undang Dasar Negara Republik Indonesia Tahun 1945 (UUD Negara RI 1945) adalah Negara hukum (Rechsstaats)', bukan negara berdasarkan kekuasaan belaka (Machtsstaats), oleh karena itu semua elemen dalam melaksanakan tindakan apapun harus dilandasi oleh hukum yang dapat dipertanggungjawabkan. Adapun prinsip-prinsip yang terkandung dalam negara hukum Indonesia menurut Jimly Asshiddiqie sebagaimana dikutip oleh Haryanto dapat dibagi menjadi 12 (dua belas) macam:²

1. Supremasi Hukum (Supremacy of Law);

2. Persamaan dalam Hukum (Equality before the Law);

3. Asas Legalitas (Due Process of Law);

4. Pembatasan Kekuasaan;

5. Organ-Organ Eksekutif Independen;

6. Peradilan Bebas dan Tidak Memihak;

7. Peradilan Tata Usaha Negara;

8. Peradilan Tata Negara (Constitutional Court);

9. Perlindungan Hak Asasi Manusia;

10. Bersifat Demokratis (Democratische Rechtsstaat);

11. Berfungsi sebagai Sarana Mewujudkan Tujuan Bernegara (Welfare Rechtsstaat);

12. Transparansi dan Kontrol Sosial.

Prinsip-prinsip yang terkandung di dalam negara hukum, berkaitan dengan Hak Asasi Manusia (HAM), karena HAM adalah

1'Indonesia, Undang-Undang Dasar Negara RI 1945, Pasal 1 ayat (3), (Lembaran Negara Republik Indonesia Tahun 1959 No. 75).

${ }^{2}$ Haryanto, "Prinsip Pokok Negara Hukum", (On-line), tersedia di WWW: //http: haryantogago.blog.friendster.com200811prinsip-pokok-negarahukum. (03 Maret 2011). 
Pakuan Law Review Volume 4

Nomor 2, Juli-Desember 2018

e-ISSN:2614-485

hak-hak dasar atau hak-hak pokok yang dibawa manusia sejak lahir sebagai anugerah Tuhan Yang Maha Esa. Hak-hak asasi ini menjadi dasar dari hak-hak dan kewajiban-kewajiban yang lain. ${ }^{3}$

Hukum dan hak asasi warga negara erat sekali hubungannya terutama dalam negara hukum seperti Indonesia.Warga negara adalah subyek hukum yang harus dilindungi oleh hukum buatan manusia baik yang tertulis seperti undang-undang tertentu maupun hukum yang tidak tertulis seperti hukum adat yang berlaku dalam masyarakat tradisional. Hukum bagi umat manusia, ditinjau dari HAM sebenarnya untuk memformalkan hak-hak dasar tersebut, dan bukan mematikan HAM. ${ }^{4}$

The right of due process adalah suatu prinsip dalam hukum pidana yang mempunyai arti bahwa setiap tersangka berhak diselidiki dan disidik di atas landasan "sesuai dengan hukum acara". Hak due process dalam melaksanakan tindakan penegakan hukum, bersumber dari cita-cita "negara hukum" yang menjunjung tinggi "Supremasi hukum" the law is supreme) yang menegaskan "kita diperintah oleh hukum dan bukan oleh orang" (goverment of law and not of me ). 5

3Artasite. "Asas Hukum" (On-line), tersedia di WWW: http://artasite.blogspot.com/2010/11/asas-hukum.html, (03 Maret 2011).

${ }^{4}$ Hutabarat, Ramly.Persamaan Dihadapan Hukum (Equality Before The Law) Di Indonesia, (Jakarta: Ghalia Indonesia, Cetakan Pertama 1985), hal 25. 5"Prinsip The Right Of Due Procces Of Law Dalam Proses Penyelidikan Dan Penyidikan" (On-line),tersedia di WWW: http://yudipriambudish.blogspot.com/2009/05/prinsip-right-of-due-processof-law.html, (03 Maret 2011). 
Pakuan Law Review Volume 4

Nomor 2, Juli-Desember 2018

e-ISSN:2614-485

\section{B. Dasar Hukum Penangkapan}

Wewenang yang diberikan kepada penyidik sedemikian luasnya, bersumber atas wewenang yang diberikan undang-undang tersebut, penyidik berwenang mengurangi kebebasan dan hak asasi seseorang, asalkan hal itu masih berpijak pada landasan hukum. Wewenang pengurangan kebebasan dan hak asasi seseorang, harus dihubungkan dengan landasan prinsip hukum yang menjamin terpeliharanya harkat martabat kemanusiaan seseorang serta tetap berpedoman pada landasan orientasi keseimbangan antara perlindungan kepentingan tersangka pada satu pihak, dan kepentingan masyarakat serta penegakan ketertiban hukum pada pihak lain. ${ }^{6}$

Untuk mencegah agar polisi tidak bertindak sewenangwenang dalam melaksanakan wewenang untuk menangkap seseorang, maka undang-undang menetapkan batas wewenang polisi. Pembatasan tersebut meliputi empat dimensi ruang lingkup yaitu:

1. Batas kekuasaan wilayah dalam menangkap orang; ${ }^{7}$

6Sitompul. DPM, Polisi Dan Penangkapan (Bandung: Tarsito, Cetakan Pertama 1985), hal 19.

${ }^{7}$ Ibid, hal. 20. Wilayah-wilayah istimewa yang tidak boleh dilanggar Polri dalam tugas penangkapan yaitu:

a. Wilayah/daerah exsteritorialitet yaitu suatu wilayah berdasarkan hukum Internasional mempunyai hak-hak istimewa yang kebal terhadap tindakan kepolisian, termasuk di dalamnya tindakan penangkapan;

b. Wilayah/daerah di kapal perang negara asing yang secara resmi sedang berkunjung dan berlabuh di perairan RI; 
Pakuan Law Review Volume 4

Nomor 2, Juli-Desember 2018

e-ISSN:2614-485

2. Batas kekuasaan permasalahan; ${ }^{8}$

3. Batas kekuasaan manusia yang boleh ditangkap; ${ }^{9}$

4. Batas kekuasaan waktu dalam menangkap orang. 10

Wewenang polisi didasarkan pada 2 (dua) asas pokok, yaitu:11

1. Asas Legalitas

Petugas polisi dalam melaksanakan tindakannya selalu berdasarkan peraturan-peraturan yang dicantumkan dalam perundang-undangan. Asas legalitas ini biasanya

c. Daerah Internasional yaitu: suatu daerah dimana ditempatkan pasukan Internasional bantuan dari Perserikatan Bangsa-Bangsa (PBB) yang bertugas untuk mengawasi keamanan daerah tersebut.

8Ibid., hal. 24. Pada hakikatnya tugas polisi secara garis besarnya menyangkut masalah-masalah:

a. Masalah penegakan hukum;

b. Masalah menyelenggarakan ketentraman masyarakat;

c. Masalah memberi perlindungan dan pelayanan kepada masyarakat.

${ }^{9}$ Ibid., hal. 36. Orang-orang asing yang mempunyai hak eksteritorialitas menurut Internasional yakni:

a. Kepala negara asing yang berkunjung ke Indonesia dengan sepengetahuan pemerintah Indonesia;

b. Para petugas diplomatik dari negara-negara asing;

c. Para konsul;

d. Pasukan-pasukan tentara asing dan para anak buah kapal perang asing yang datang di Indonesia atau melalui perairan laut wilayah Indonesia dan dengan satau pemerintah Indonesia.

Disamping adanya hak eksteritorialitas yang harus diperhatikan oleh setiap petugas polisi, jugaada beberapa ketentuan khusus tentang tata cara menangkap orang yang diperlukan bagi warga negara Indonesia tertentu, sehubungan dengan jabatan orang tersebut, misalnya:

a. Tindakan kepolisian terhadap anggota/pimpinan MPR/DPR;

b. Tindakan kepolisan terhadap anggota TNI;

c. Tindakan kepolisian terhadap kepala wilayah Propinsi/Ibu kota Negara.

${ }^{10}$ Ibid., hal. 40. Penuntutan hukuman itu dibatasi dengan kekuatan waktu yang disebut dengan kadaluwarsa atau verjaring.

11 Ibid., hal. 66. 
Pakuan Law Review Volume 4

Nomor 2, Juli-Desember 2018

e-ISSN:2614-485

diperlukan dalam tugas "Represif Yustisional" artinya tugas-tugas penindakan untuk kepentingan peradilan pidana.

2. Asas Kewajiban

Wewenang yang diberikan kepada petugas polisi untuk bertindak sesuai dengan tugas dan kewajibannya walaupun tindakan polisi tersebut tidak tercantum secara tegas dalam peraturan undang-undang. Jadi dalam asas kewajiban ini petugas polisi diberi wewenang untuk bertindak berdasarkan penilaiannya sendiri dalam menghadapi permasalahan demi terjaminnya keamanan dan ketertiban masyarakat. ${ }^{12}$

Tindakan penangkapan dalam hal ini bersifat represif, ada hubungannya dengan peradilan, yaitu untuk kepentingan penyidikan atau penuntutan dan atau peradilan. Dasar hukum penangkapan dinyatakan dalam Pasal 17 KUHAP, yang berbunyi

12Ibid. Untuk memghindari tindakan sewenang-wenang dari polisi dalam menerapkan asas kewajiban tersebut, menurut Drs. Soebroto Brotodiredjo, SH, dibatasi dengan empat ketentuan yaitu:

a. Asas keperluan, tindakan hanya dapat diambil apabila betul-betul diperlukan untuk meniadakan suatu gangguan atau mencegah terjadinya suatu gangguan;

b. Asas masalah sebagai patokan, tindakan yang diambil akan dikaitkan dengan masalah yang perlu ditangani;

c. Asas tujuan, tindakan yang betul-betul mencapai saran, ialah hilangnya suatu gangguan atau tidak terjadinya sesuatu yang dikhawatirkan;

d. Asas keseimbangan, tindakan kepolisian hendaknya dijaga suatu keseimbangan antara sifat keras dan lunaknya tindakan, atau sarana yang dipergunakan pada satu pihak, dan besar kecilnya suatu gangguan atau berat ringannya suatu objek yang harus ditindak pada pihak lain. 
Pakuan Law Review Volume 4

Nomor 2, Juli-Desember 2018

e-ISSN:2614-485

sebagai berikut :"Perintah penangkapan dilakukan terhadap seseorang yang diduga keras melakukan tindak pidana berdasarkan bukti permulaan yang cukup".13 Unsur-unsur yang tersirat dalam Pasal 17 KUHAP, menyatakan bahwa seseorang dapat ditangkap karena :14

1. Seorang tersangka diduga keras melakukan tindak pidana; dan

2. Dugaan yang kuat itu, didasarkan pada pemulaan bukti yang cukup.

Dengan demikian, dapat dilihat bahwa dasar hukum bagi penangkapan adalah :15

\section{Adanya dugaan keras}

Prinsip utama dalam melakukan penangkapan adalah tidak boleh dilakukan secara gegabah, maksudnya perlu ada terlebih dahulu "dugaan yang keras melakukan tindak pidana", artinya bahwa seseorang memang telah melakukan tindak pidana berdasarkan niat, maksud, dan lain sebagainya. KUHAP tidak menjelaskan apa yang dimaksud dengan "diduga keras". Pengertian "diduga keras" akan berhubungan dengan

13Indonesia. Kitab Undang-Undang Hukum Acara Pidana (KUHAP). UU No. 8Tahun 1981. LN No. 76 Tahun 1981.

${ }^{14}$ Ibid.,

${ }^{15}$ Syamsul Bahri Rajam, Hukum Warganegara Dalam Hukum Acara Pidana, Dalam Panduan Bantuan Hukum di Indonesia pedoman Anda Memahami dan Menyelesaikan Masalah Hukum, editor: A. Zien dan Daniel Hutagalung, edisi pertama, (Jakarta: Yayasan Lembaga Bantuan Hukum Indonesia dan Pusat Studi Hukum dan Kebijakan, 2006), hal 238. 
"dugaan", yang membedakan antara "patut diduga" dan "sangat diduga". 16

Apa yang dimaksud dengan "diduga keras" dalam KUHAP akan lebih tepat apabila diidentikkan dengan "sangat diduga", sehingga untuk menangkap seseorang yang diduga telah melakukan tindak pidana tidak cukup apabila orang itu "patut diduga" telah melakukan suatu tindak pidana, melainkan harus ada bukti-bukti yang menunjang bahwa orang tersebut "sangat diduga" telah melakukan tindak pidana. ${ }^{17}$

\section{Bukti permulaan yang cukup}

Yang dimaksud dengan "bukti permulaan yang cukup" menurut penjelasan Pasal 17 KUHAP adalah bukti permulaan "untuk menduga" adanya tindak pidana sesuai dengan bunyi Pasal 1 butir 14 KUHAP. Selanjutnya penjelasan Pasal 17 KUHAP menyatakan "Pasal ini menunjukkan bahwa perintah penangkapan tidak dapat dilakukan dengan sewenangwenang, tetapi ditujukan kepada mereka yang betul-betul melakukan tindak pidana".

Rasional dan realistis, apabila perkataan "permulaan" dibuang, sehingga kalimat itu berbunyi "diduga keras melakukan tindak pidana berdasarkan bukti yang cukup". Jika seperti ini rumusan Pasal 17 KUHAP, pengertian dan penerapannya lebih pasti. Jika tidak salah tangkap, pengertian

16Andi Hamzah, Pengantar Hukum Acara Pidana Indonesia, (Jakarta:Pradnya Paramita, 1984), hal. 60.

${ }^{17}$ Ibid. 
yang dirumuskan dalam pasal itu hampir sama dengan pengertian yang terdapat pada hukum acara pidana Amerika, yang menegaskan bahwa untuk melakukan tindakan penangkapan atau penahanan, harus didasarkan atas affidavit and testimony, yakni harus didasarkan pada adanya bukti dan kesaksian. ${ }^{18}$

Kalau ketentuan Pasal 17 KUHAP dipedomani oleh penyidik dengan sungguh-sungguh, maka dapat diharapkan suasana penegakan hukum yang lebih objektif, maka penyidik tidak lagi sembarangan melakukan penangkapan. Sebab jika ditelaah, pengertian bukti permulaan yang cukup, hampir serupa dengan apa yang dirumuskan dalam Pasal 183 KUHAP, yakni harus berdasar prinsip "batas minimal pembuktian" yang terdiri sekurang-kurangnya dua alat bukti bisa terdiri dari dua orang saksi atau saksi ditambah satu alat bukti lain.

Definisi bukti permulaan yang cukup berdasarkan penjelasan Pasal 17 KUHAP, bukti permulaan yang cukup adalah "Bukti permulaan untuk menduga adanya tindak pidana sesuai dengan bunyi pasal 1 butir 14". Sementara Pasal 1 butir 14 KUHAP menyatakan "Bahwa tersangka adalah seseorang yang karena perbuatan atau keadaannya, berdasarkan bukti permulaan patut diduga sebagai pelaku tindak pidana". Berdasarkan Hasil Rapat Kerja Gabungan Mahkamah Agung, Kehakiman, Kejaksaan, Kepolisian

${ }^{18} \mathrm{M}$ Yahya Harahap, Pembahasan Permasalahan dan Penerapan KUHAP, edisi kedua, (Jakarta: Sinar Grafika, 2008),hal. 158. 
(Rakergab Makehjapol) 1 Tahun 1984 halaman 14, dirumuskan bahwa yang dimaksud dengan bukti permulaan yang cukup, seyogyanya minimal laporan polisi ditambah dengan salah satu alat bukti lainnya. ${ }^{19}$

Sedangkan dalam Penetapan Pengadilan Negeri Sidikalang Sumatera Utara No.4/Pred-Sdk/1982, 14 Desember 1982, bukti permulaan yang cukup harus mengenai alat-alat bukti yang diatur dalam Pasal 184 (1) KUHAP bukan yang lain-lainnya seperti: laporan polisi dan sebagainya. Pengertian bukti permulaan menurut Keputusan Kapolri No Pol.SKEEP/04/I/1982, 18-2-1982, adalah bukti yang merupakan keterangan dan data yang terkandung di dalam dua diantara: ${ }^{20}$

1. Laporan polisi;

2. BAP di TKP;

3. Laporan Hasil Penyelidikan;

4. Keterangan saksi atau ahli dan;

5. Barang bukti.

Menurut Harun M. Husein, bila laporan polisi ditambah dengan salah satu alat bukti (keterangan saksi pelapor atau pengadu) dirasakan masih belum cukup kuat untuk dijadikan bukti permulaan yang cukup guna dipergunakan sebagai alasan penangkapan seseorang. Terkecuali apabila laporan polisi dimaksud diartikan sebagai laporan hasil penyelidikan

${ }^{19}$ Harun M. Husein.Penyidikan dan Penuntutan Dalam Proses Pidana, (Jakarta: Rineka Cipta, 1991), hal 112.

${ }^{20}$ Ibid., hal 113. 
yang berisi tentang kepastian bahwa suatu peristiwa yang semula diduga sebagai tindak pidana, adalah benar-benar merupakan suatu tindak pidana, terhadap tindak pidana yang dapat dilakukan penyidikan karena tersedia cukup alat bukti untuk melakukan penyidikan. ${ }^{21}$

\section{Surat Perintah Penangkapan}

Surat perintah penangkapan dalam perspektif hukum acara pidana bukan merupakan perihal utama dalam konteks pembuktian, karena menurut ketentuan Pasal 184 ayat (1) KUHAP disebutkan:

a. Keterangan saksi;

b. Keterangan ahli;

c. Surat;

d. Keterangan petunjuk;

e. Keterangan terdakwa.

Keterangan saksi kedudukannya dalam perspektif pembuktian hukum pidana lebih tinggi dari pada surat atau dokumen tertulis lainnya baik otentik atau tidak otentik. Berbeda halnya dengan pembuktian dalam perspektif hukum perdata. Kedudukan hukum sebuah surat atau dokumen tertulis lainnya baik otentik ataupun tidak otentik dalam perspektif hukum privat atau perdata lebih tinggi daripada keterangan saksi atau keterangan ahli. Dalam perkembangan masalah sistem pembuktian dalam hukum pidana atau hukum acara 
pidana selalu berubah, sesuai dengan perkembangan ilmu pengetahuan dan tekhnologi.

\section{Tembusan Surat Perintah}

Menurut ketentuan Pasal 18 ayat (3) KUHAP menunjukkan bahwa tembusan surat perintah penangkapan harus disampaikan kepada keluarga tersangka, dalam hal tidak diketahui alamat/tempat tinggal tersangka menimbulkan kesulitan dalam pelaksanaannya. Karena hal ini memungkinkan terputusnya informasi antara tersangka dan keluarga tersangka, padahal pemberitahuan kepada keluarga tersangka menjadi hal yang amat substanstif. Karena itu pembuatan dan penulisan dalam tembusan surat penangkapan harus diperhatikan dengan seksama dan hati-hati. Jika ada kesalahan dalam segi pembuatan dan penulisannya akan mengandung kecacatan hukum, maka proses penangkapan menjadi tidak sah bahkan bisa berakibat tidak sah secara prosedur hukum. Di dalam surat pembuatan penangkapan, mesti memuat dan mencantumkan: pertama, identitas tersangka; kedua alasan tersangka; ketiga, uraian singkat kejahatan yang disangkakan; dan keempat, tempat pemeriksaan.

\section{Pemanggilan secara patut}

Jangka waktu penangkapan hanya berlaku paling lama untuk jangka waktu 1 x 24 jam (satu kali dua puluh empat jam). Apabila dalam waktu lebih dari 1 x 24 jam (satu kali dua puluh empat jam), tersangka tidak boleh ditahan, harus dilepaskan, namun untuk pemeriksaan dapat dilanjutkan. Dengan demikian 
seorang Penyidik dalam melaksanakan penangkapan, wajib dan harus memperhatikan 4 (empat) hal, antara lain:

a. Untuk kepentingan penyelidikan dan penyidikan;

b. Adanya dugaan keras berdasarkan bukti permulaan yang cukup, bahwa orang tersebut tersangkut dalam tindak pidana;

c. Perbuatan yang dilakukan adalah tindak pidana; dan

d. Tersangka pelaku pelanggaran tidak dilakukan penahanan kecuali secara sah dipanggil dua kali berturut-turut, tidak datang menghadap tanpa alasan yang sah. ${ }^{22}$

Pasal-pasal tersebut di atas telah menunjukkan bahwa perintah penangkapan tidak dapat dilakukan polisi dengan sewenang-wenang atau semaunya serta harus diperhatikan sesuai dengan prosedur peraturan perundang-undangan yang berlaku (khususnya KUHAP). Dengan demikian penangkapan seharusnya ada dasar hukum yang kuat dan tepat yang menyatakan atau menegaskan bahwa ialah pelakunya. Terhadap seorang tersangka tindak pidana, pelanggaran salah tangkap tidak ada kaitan sama sekali dengan diadakannya penangkapan. Ia hanya dipanggil atau diperintahkan secara hukum dua kali berturut-turut, dan apabila tidak memenuhi panggilan penyidik tanpa alasan yang sah, maka dengan segera petugas penyidik mengeluarkan surat perintah penangkapan sesuai dengan ketentuan yang diatur dalam Pasal 112 KUHAP.

${ }^{22}$ Sitompul. DPM, Op. Cit., hal. 8. 
Pakuan Law Review Volume 4

Nomor 2, Juli-Desember 2018

e-ISSN:2614-485

\section{Faktor - Faktor Penyebab Sering Terjadinya Kasus Salah Tangkap}

Kasus salah tangkap dapat terjadi karena tindakan non profesional yang dilakukan oleh pihak kepolisian dalam menjalankan prinsip-prinsip kriminalisasi mulai dari mendeteksi kejahatan, identifikasi korban, tersangka dan korelasinya secara ilmiah. Informasi Tempat Kejadian Perkara (TKP), barang bukti, dan cara kerja aparat tidak mendukung kebenaran, sehingga putusan pengadilan juga jatuh pada orang yang tidak salah. Padahal ini adalah hukum pidana yang menyangkut kepentingan orang banyak.

Di masa Orde Baru, ada beberapa hal yang harus dilawan oleh polisi, yakni dependensi dan intervensi kekuasaan. Pada era reformasi, polisi mengambil posisi sebagai polisi sipil yang harus memperhatikan aspek profesionalisme. Namun, polisi profesional bukanlah jargon yang mudah diubah seketika. Mungkin di kalangan elite dapat diserap secara cepat karena beberapa hal, misalnya polisi elite tidak menangani kasus-kasus yang tanpa perhatian masyarakat secara umum. Tingkat pendidikan mereka juga lebih tinggi dibandingkan dengan polisi di tingkat bawah. ${ }^{23}$

Unsur penyebab dapat terjadinya salah tangkap atau kesalahan tangkap dapat dilihat dari aspek:

1. Subyek hukum

Subyek hukum dalam perspektif hukum pidana dapat berupa seseorang dan atau sekumpulan orang. Dalam kaitannya

${ }^{23}$ Erlangga Masdiana, "Polisi dan Fenomena Salah Tangkap",(Jakarta : Gatra, 2008), hal. 76. 
dengan salah tangkap atau kesalahan tangkap, penyidik dan atau penyelidik telah melakukan kesalahan dan kekeliruan dalam menangkap orang lain (baik seseorang atau sekumpulan orang) yang dianggap menurut sangkaan atau dugaan penyidik atau penyelidik sedang atau sudah melakukan sebuah tindak pidana. Sehingga seseorang atau sekumpulan orang tersebut tidak memiliki keterkaitannya dengan suatu tindak pidana.

2. Objek hukum

Objek hukum yang dapat menyebabkan terjadinya salah tangkap bisa berupa:

a. Kesalahan objek wilayah atau tempat peristiwa kejadian di mana suatu tindak pidana sedang atau sudah dilakukan. Adanya salah tangkap yang dikarenakan oleh kesalahan tempat menyebabkan dasar hukum yang dipergunakan menjadi kabur, tidak jelas, menyesatkan, sehingga hal ini berakibat batal secara hukum; dan

b. Sedangkan selain tempat atau wilayah kejadian yang menyebabkan terjadinya salah tangkap ialah, objek barang atau benda yang menjadi bukti permulaan telah terjadinya suatu tindak pidana. Benda atau barang yang dapat dijadikan bukti suatu tindak pidana sedang atau telah terjadi mempunyai kedudukan dan dasar hukum yang penting. Kesalahan oleh Penyidik atau Penyelidik dalam "mengidentifikasi" benda atau barang yang dapat dijadikan bukti dapat menyebabkan bahwa penyidikan tersebut mengandung kecacatan hukum dan menjadi tidak 
sempurnanya suatu proses penyidikan atau penyelidikan. Akibatnya hal tersebut dapat membatalkan secara hukum tentang penangkapan.

Jika terjadi suatu salah tangkap atau kesalahan tangkap yang dilakukan oleh penyidik atau penyelidik terhadap orang lain yang disangka sedang atau sudah melakukan suatu tindak pidana sehingga menimbulkan kelalaian, maka dalam perspektif pemulihan hak asasi manusianya, penyidik atau penyelidik dapat dikenakan ketentuan kaidah pidana khusunya diancam dengan Pasal 333 ayat (1), ayat (2), dan ayat (4) KUHP, yang menyatakan:

Pasal 333

(1) Barangsiapa dengan sengaja dan melawan hukum merampas kemerdekaan seseorang, atau meneruskan perampasan kemerdekaan yang demikian, diancam dengan pidana penjara paling lama delapan tahun.

(2) Jika perbuatan itu mengakibatkan luka-luka berat, maka yang bersalah dikenakan pidana penjara paling lama sembilan tahun.

(3) Jika mengakibatkan mati, dikenakan pidana penjara paling lama dua belas tahun.

(4) Pidana yang ditentukan dalam Pasal ini berlaku juga bagi orang yang dengan sengaja memberi tempat untuk perampasan kemerdekaan yang melawan hukum.

Ada beberapa faktor yang mempengaruhi polisi terjebak dalam suatu kesalahan dalam melakukan penangkapan, sehingga polisi dikenal telah melakukan suatu tindakan salah tangkap, yaitu : 


\section{Dinamika kerja begitu kompleks}

Polisi dihadapkan pada kasus-kasus yang harus disidik, mulai kasus konflik dalam rumah tangga hingga teror bom, baik yang bersifat kasus delik aduan maupun bukan delik aduan. Amat banyak kejahatan karena laporan masyarakat atau hasil patroli yang harus ditindaklanjuti. Tentu saja masyarakat juga berharap agar setiap kasus dapat diselesaikan dengan cepat. ${ }^{24}$

Namun cara menyelesaikan kasus kejahatan juga mendapat sorotan masyarakat. Polisi yang bersikap tegas akan mendapat reaksi keras dari masyarakat. Polisi yang mengikuti prosedur secara hati-hati pun akan dicaci karena amat lamban. Bahkan untuk berbagai kasus yang mendapat perhatian masyarakat, seperti narkoba, polisi harus mengikuti prosedur, misalnya adanya barang bukti yang jelas. Padahal apa yang dirasakan dan dilihat masyarakat belum tentu bisa dijadikan barang bukti. Tak ayal lagi, polisi harus melepas tersangka karena kurangnya bukti. Masyarakat pun lantas menuduh polisi main mata dengan tersangka. 25

Banyaknya kasus yang diselesaikan (clearance rate) juga dikaitkan dengan profesionalitas polisi. Model penanganan polisi secara cepat seperti ban berjalan, karena setiap kasus yang masuk ke institusi kepolisian harus hal. 32 .

${ }^{24}$ Andi Hamzah. Kekerasan Oleh Polisi,(Jakarta : Sinar Grafika, 2004), 25Ibid., hal. 34 . 
diselesaikan secara cepat. Namun kualitas penanganan juga seperti tanpa memperhatikan aspek humanitas. ${ }^{26}$

\section{Kurangnya sumber daya manusia polisi dalam menentukan tingkat pelayanan dan penanganan kasus-} kasus kejahatan

Perilaku manusia dapat bersifat nyata, tapi lebih banyak bersifat pseudo (samar-samar). Dinamika perilaku sosial menyulitkan polisi untuk dapat memprediksi apa yang akan terjadi. Polisi lebih sering mendapat laporan dari masyarakat tentang apa yang sudah terjadi.27 Oleh karena itu, polisi yang menangani perkara mestinya memiliki ilmu pengetahuan tentang kepolisian dan ilmu-ilmu lain seperti sosiologi, kriminologi, psikologi, komputer, ekonomi, hukum dan lainlain. Polisi tidak bisa lagi memaksa orang mengakui suatu perbuatan dengan cara-cara lama. Teknologi kepolisian sudah harus dikembangkan.

Di sini, polisi harus lebih cermat dan dapat membangun kesimpulan, yang didasarkan pada bukti atau keterangan saksi. Cara memperoleh bukti tentu tidak lagi statis, tapi ditunjang dengan berbagai metode pembuktian yang canggih. Sampai saat ini, pihak kepolisian masih menggunakan caracara yang lama dalam menyusun suatu pembuktian. Akibatnya banyak terjadi peristiwa salah tangkap yang dilakukan oleh

${ }^{26}$ Ibid.,hal. 34.

${ }^{27}$ Satjipto Rahardjo, Membangun Polisi Sipil, (Jakarta: Kompas Media Nusantara, Cet kedua, 2007), hal. 113. 
kepolisian karena tidak menggunakan teknologi yang sudah seharusnya dipergunakan ditambah dengan sumber daya manusia yang tidak memadai.

Namun menyertakan pengacara dalam proses penyidikan juga menjadi persoalan pelik. Kepelikan itu dipengaruhi oleh faktor-faktor sebagai berikut :

a. Resistensi polisi untuk enggan disertakan pengacara;

b. Tersangka tidak mampu menyertakan pengacara, dan

c. Negara masih terbatas membantu kelompok masyarakat yang tidak mampu untuk disertakan pengacara. ${ }^{28}$

Tidak jarang polisi atas nama negara melakukan proses penyidikan dengan keterbatasan anggaran yang dimilikinya. Hal inilah yang akhirnya akan menimbulkan suatu masalah, yaitu polisi bertindak acuh tak acuh atas pekerjaannya, karena negara tidak mau memperhatikan kebutuhan anggota kepolisian, sehingga pada akhirnya kinerja kepolisian dipertanyakan seiring dengan seringnya kasus salah tangkap oleh pihak polisi. ${ }^{29}$

Salah tangkap bisa disebabkan kurang atau tidak profesionalnya petugas reserse kepolisian. Ini bisa menyangkut masalah rekrutmen dan pendidikan. Rekrutmen terutama berkaitan dengan syarat akademis maupun karakter polisi, sedangkan pendidikan terutama berkaitan dengan kurikulum, metode pengajaran, dan teknis pengajarannya 
sendiri. Dalam pendidikan polisi, cenderung banyak diberikan pengetahuan dibanding keterampilan. Padahal, pekerjaan polisi itu lebih menuntut keterampilan. Ini persentasenya lebih besar. Juga metode atau cara pengajarannya harus bersifat dialogis, tidak monologis layaknya seperti seorang instruktur dalam pendidikan di militer. ${ }^{30}$

\section{Proses penyidikan yang sangat sulit}

Polisi di sini harus mengerutkan dahi bagaimana menghadapi berbagai perilaku tersangka. Sebab, para tersangka acapkali berbohong, berkelit, membantah, atau tidak mau mengakui kejahatan yang dilakukannya.

Berdasarkan berbagai perilaku penjahat yang double standard itulah, para penyidik sering menyamaratakan bahwa semua yang diinterogasi adalah orang yang bersalah. Sampai akhirnya, berdasarkan suatu kesimpulan, bahwa orang tersebut tidak terbukti kesalahannya.

Polisi bagaikan merangkai pecahan gelas. Puing-puing yang berserakan harus ditelusuri posisinya di mana. Seni merangkai inilah yang harus dibuktikan oleh polisi. Rangkaian pecahan itulah yang dimaksud sebagai bukti-bukti yang mengarahkan seseorang menjadi orang yang layak mendapatkan dakwaan. ${ }^{31}$

${ }^{30}$ Bambang Widodo Umar, "Korban Salah Tangkap Sering Kalah Melawan Polisi" (On-line), tersedia di WWW:http://www.suarakaryaonline.com/news.html?id=208687 (16 Februari 2011).

${ }^{31}$ Erlangga Masdiana, Op. Cit., hal. 77. 
Merangkai pecahan gelas itu pasti sulit dan tingkat kesalahannya tinggi. Namun polisi selalu menggunakan berbagai cara untuk memperoleh bukti pecahan-pecahan tersebut dari ketentuan KUHAP. Dalam menjalankan ketentuan itu, polisi harus berlandaskan pada prinsip-prinsip penyidikan.

Kesalahan penyidikan bisa terjadi karena petunjuknya kurang jelas, misalnya jika dikaitkan dengan bentuk peristiwa pidana dan bentuk atau kondisi Tempat Kejadian Perkara (TKP), atau kerena petugas reserse yang tidak cermat dalam mengumpulkan atau mencari barang bukti. Selain petunjuk yang berisi ketentuan tentang olah TKP, diperlukan juga pentunjuk atau ketentuan tentang pengambilan Deoxyribose Nucleic Acid ( DNA) untuk temuan mayat. Namun tentang hal ini belum diatur. Bagaimana kriteria mayat yang ditemukan, rusak, setengah rusak, atau tidak rusak, yang wajib diambil DNA nya dan yang tidak wajib diambil DNA nya. ${ }^{32}$

\section{Target atasan untuk segera menyelesaikan kasus tertentu}

\section{dalam waktu cepat}

Dalam hal ini, pengabaian hak-hak tersangka acap menonjol. Berbagai metode ilmiah penyidikan

\footnotetext{
${ }^{32}$ Bambang Widodo Umar, "Korban Salah Tangkap Sering Kalah Melawan Polisi" (On-line),tersedia di http://www.suarakarya-online .com/news.html?id=208687, (16 Februari 2011).
} 
dikesampingkan, yang terpenting adalah pengakuan tersangka. ${ }^{33}$

Adanya suatu target tertentu dalam menyelesaikan suatu kasus membuat pihak kepolisian kerap mengabaikan hal-hal yang dianggap penting dalam pembuktian atau karena tekanan dari pimpinan yang berambisi mengejar prestasi atau karena beban tugas yang over load tanpa mempedulikan kemampuan anggota. Dalam pembuktian diperlukan alat-alat bukti yang cukup agar seseorang dapat dijatuhi pidana.Namun dengan adanya suatu target tertentu, maka hanya dibutuhkan suatu pengakuan dari seseorang yang disangka telah melakukan perbuatan pidana, padahal orang tersebut sama sekali tidak melakukan perbuatan pidana. ${ }^{34}$

Segala bentuk kelemahan, kelalaian, dan kesengajaan oknum polisi sebenarnya dapat divalidasi oleh institusi kejaksaan dan hakim di pengadilan bila jaksa dan hakim dalam mengungkap kasus itu menggunakan cara yang standar. Misalnya ada suatu keterangan yang bertentangan, apalagi barang bukti yang ada sulit diterima akal sehat, maka selayaknya diperiksa kembali. Bukan hanya mendasar- kan diri pada BAP di kepolisian.

Mungkin juga apa yang dikerjakan polisi atau hakim sama, yaitu kasus yang begitu banyak dan harus diselesaikan dengan cepat. Jumlah jaksa dan hakim amat sedikit apabila 
dibandingkan dengan kasus-kasus yang dihadapi. Selain banyaknya kasus, ada lagi faktor-faktor lain yang mempengaruhi kinerja mereka, misalnya gaji yang tidak memadai, budaya hukum yang tidak kondusif, sistem karier, tingkat kecerdasan dan pengetahuan yang terbatas, serta masih banyak lagi faktor yang mengabaikan aspek profesionalitas.

Sebaliknya, anggota masyarakat yang terkena kasus salah tangkap atau kelalaian petugas kepolisian semestinya melakukan kontrol lebih lugas. Adapun hak-hak tersangka dipahami sebagai hak-hak istimewa yang perlu dipelajari. Namun hal yang perlu diingat adalah jangan pula menyerahkan semua kasus hukum itu sepenuhnya kepada polisi, jaksa dan hakim, sebab ternyata hukum di Indonesia masih memperhatikan aspek kontrol dan rekontrol.

\section{Pertanggungjawaban Pidana Penyidik Polri Dalam Kasus Salah Tangkap}

Ketika berkas-berkas perkara (berita acara, alat bukti, barang bukti) dari kepolisian dinyatakan sudah lengkap oleh kejaksaan maka kejaksaan segera menyiapkan penuntutan untuk mengajukan tersangka ke depan pengadilan (menjadi terdakwa). Apabila hakim merasa sudah tersedia cukup bukti bahwa terdakwa telah melakukan kejahatan tersebut, keluarlah vonis hukuman penjara. 
Dilihat dari prosesnya, maka tahapan-tahapan tadi saling tergantung satu sama lain. Apabia terjadi kesalahan/kekeliruan di tingkat kepolisian, kemudian tetap dilanjutkan, maka vonis yang diberikanpun bisa salah. Dalam hal ini akan timbul suatu pertanyaan, apakah ini bisa terjadi? Jawabannya adalah tentu saja hal ini bisa terjadi, dan ini sudah beberapa kali terjadi.

Begitu kasus salah tangkap yang berawal dari pengakuan Ryan dan hasil forensik mencuat, banyak sekali yang berkomentar dan berpendapat. Bahkan, Komisi Yudisialpun menyatakan bahwa ini menyangkut masalah integrated criminal justicesystem. Harusnya, jaksa dan hakim peka untuk menganalisanya. Pihak keluarga pun menuntut untuk membebaskan anggotanya yang telah dipenjara dan yang sedang diproses. Anehnya, belum terdengar berkomentar bahwa pihak-pihak yang berkepentingan atas kesalahan proses pengadilan tersebut juga dapat disangka atas sebuah perbuatan pidana.

Baik polisi, jaksa dan hakim yang memproses kasus tersebut telah berbuat atau tidak "berbuat" (dalam istilah hukum pidana, kejahatan dapat dilakukan dengan sebuah "perbuatan" dan bisa juga dengan "tidak berbuat" atau "pembiaran") sesuatu sehingga terjadi tindak pidana. Namun, perbuatan pidana yang telah dilakukan oleh penegak hukum tersebut apakah dapat dipidana ? Apakah karena mereka menjalankan tugasnya berdasarkan undang-undang, maka apabila mereka melakukan perbuatan pidana maka mereka tidak dapat dijatuhi pidana? 
Pakuan Law Review Volume 4

Nomor 2, Juli-Desember 2018

e-ISSN:2614-485

Coba bandingkan dengan kejahatan lain, seperti tanggung jawab pidana seorang pilot atas kecelakaan pesawat yang mengakibatkan tewasnya para penumpang. Atau tanggungjawab seorang dokter atas pekerjaan yang dilakukannya. Keduanya dapat diminta pertanggung- jawaban pidana.

Dari sini, dapat disimpulkan siapa pun, baik atas perintah undang-undang atau bukan, tetap dapat dipidana sesuai dengan kejahatannya. Seorang polisi, jaksa atau hakim yang keliru menjalankan tugasnya dapat dikenai pidana. Memang, dalam hukum acara pidana, berlaku prosedur yang disebut dengan rehabilitasi. Namun, apakah rehabilitasi ini merupakan satusatunya hal yang dapat dilakukan apabila terjadi kasus salah tangkap? Kita lihat dari peristiwa salah tangkap pada kasus pembunuhan Asrori. Mereka (Kemat, Devid dan Sugik) yang divonis bersalah ternyata mengaku dipaksa oleh polisi untuk benar-benar mengaku sebagai pembunuh. 35

Dengan kata lain, mereka dipaksa untuk melakukan pembohongan. Dari sudut hukum acara pidana, cara-cara pemaksaaan seperti ini tidak dapat dibenarkan. Artinya, telah terjadi sebuah tindak pidana yang dapat diperberat karena polisi yang memaksanya memiliki kekuasaan atas nama undang-undang. Bayangkan, apabila mereka dituntut atas hukuman mati terhadap kejahatan yang tidak pernah dilakukannya, dan kemudian

\footnotetext{
${ }^{35}$ Elin Yunita Kristanti, DesyAfrianti, "13 Polisi Dihukum Minta Maaf Kepada Kemat Cs" (On-line), tersedia di WWW: http://nasional.vivanews.com/news/read/2434813_polisi_dihukum_minta_maaf pada_kemat_cs, (14 Februari 2011).
} 
dieksekusi, lalu bagaimana sebuah rehabilitasi dilakukan? Orang yang hendak direhabilitasi sudah tidak ada lagi.

Masalah kesalahan tangkap/dakwa/vonis ini terlalu mengancam hak hidup manusia, sudah seharusnya kesalahan tangkap/dakwa/vonis harus diancam secara jelas-jelas dengan pasal pidana. Undang-undang tidak boleh digunakan sebagai tameng untuk menutupi sebuah kesalahan yang notabene adalah kejahatan itu sendiri. 36

Undang-undang hanya dapat dijadikan payung hukum atas "pelanggaran" hukum yang memang sudah mengikuti prosedurnya. Apakah polisi/jaksa/hakim yang menangani kasus tersebut sudah bertindak sesuai prosedur? Tentu saja tidak sesuai prosedur. Jika sudah sesuai prosedur, apakah bisa seorang yang tidak bersalah atas sebuah perbuatan dapat dihukum? Kalau bisa, maka hukum sudah salah kaprah.

Dalam kasus-kasus administrasi, maka kesalahan prosedur hanya dikenakan kesalahan administratif, bisa berupa pangkat diturunkan atau pemecatan. Jika dilihat dalam kasus Asrori, tentu saja ini bukan hanya masalah kesalahan prosedur. Kesalahan dalam menangkap dan kesalahan prosedur merupakan dua hal yang berbeda. Keduanya terjadi dalam hal kasus ini. Adalah salah bila menganggap bahwa kesalahan menangkap terjadi karena

36Taufik Alwie, "Siapa (Pembunuh) Mr. XX”, Jakarta : Gatra, 2008, hal. 82. 
kesalahan prosedur, melainkan karena ada sebuah niat yang jahat terhadap orang lain. ${ }^{37}$

Tindakan pihak kepolisian yang telah melakukan tindakan salah tangkap sehingga merugikan orang lain, maka terhadapnya dapat dimintai pertanggungjawaban pidana, meskipun di dalam Undang-Undang No. 2 Tahun 2002 tentang Kepolisian Negara Republik Indonesia tidak dimasukkan secara eksplisit ketentuan pidana apa yang dapat dijatuhkan apabila seorang polisi telah melakukan kelalaian atau kesalahan dalam tugasnya.

Dalam hal kasus salah tangkap ini, jika dilihat dari beberapa kasus yang terjadi, kasus salah tangkap dapat dilihat dari dua bentuk, yaitu:

1. Kasus salah tangkap yang terjadi disertai dengan adanya kekerasan atau penganiayaan yang dilakukan oleh oknum penyidik Polri.

2. Kasus salah tangkap yang terjadi karena kurangnya bukti-bukti yang dituduhkan kepada seseorang yang disangka melakukan tindak pidana kejahatan. ${ }^{38}$

Kasus salah tangkap yang terjadi disertai dengan adanya kekerasan atau penganiayaan yang dilakukan oleh oknum penyidik Polri, biasanya terjadi pada saat proses pembuatan BAP, karena seorang oknum polisi membuat laporan yang tidak sesuai dengan fakta yang ada, pada saat pembuatan BAP seorang tersangka dipaksa untuk mengakui perbuatannya dengan cara menggunakan

${ }^{37}$ Ibid.,hal. 83.

${ }^{38}$ Markus Jaya Zebua, Wawancara Via Telepon Dengan Penulis, Penyidik Reskrim Polresta Bogor, Sabtu, 12 Februari 2011. 
Pakuan Law Review Volume 4

Nomor 2, Juli-Desember 2018

e-ISSN:2614-485

kekerasan atau penganiayaan. Dari kasus-kasus salah tangkap yang ada, kasus ini biasanya terungkap pada saat di persidangan atau pada saat tersangka telah diputus menjadi terpidana. Namun hal ini terjadi bukan karena ulah oknum polisi saja tetapi sudah melibatkan berbagai instansi hukum, yaitu jaksa penuntut umum dan juga hakim yang memutus perkara tersebut. Dapat dilihat dalam kasus Sengkon dan Karta (1974), Budi Harjono (2002).

Kasus salah tangkap yang terjadi karena kurangnya buktibukti yang dituduhkan kepada seseorang yang disangka melakukan tindak pidana kejahatan, dalam hal ini penyidik polisi tidak menemukan bukti yang cukup seorang yang ditangkap melakukan suatu tindakan kejahatan, sehingga orang tersebut dilepaskan. Dapat dilihat dalam kasus Wahono alias Bawor, warga Jalan Durian II, Jalan Imam Bonjol, Bandar Lampung. Ia ditangkap pasukan Detasemen Khusus 88 Antiteror beberapa waktu yang lalu. Selanjutnya, lajang 30 tahun itu dinyatakan sebagai korban salah tangkap oleh polisi dalam kasus perampokan Bank CIMB Niaga Medan $^{39}$.

Seorang polisi apabila akan bertindak menangkap orang harus yakin akan landasan hukumnya, karena sekali ia memutuskan untuk menangkap orang dan menahannya, proses penahanan tersebut akan berjalan terus dan polisi harus bertindak mempersiapkan berita acaranya, agar ia tidak dituntut ganti rugi karena salah

39"Nurochman Arazie, Sudah Gagal Kawin Jadi Korban Salah Tangkap juga" (On-line), tersedia di WWW: http://www.tempointeraktif.com/hg/hukum/2010/09/29/brk,20100929281274 ,id.html, (17 Februari 2011). 
menangkap orang. Mempelajari dan memahami pengetahuan praktis tentang hukum amat penting bagi polisi. Pengetahuan tentang nama nama jenis kejahatan tidak akan cukup sebagai bekal dasar melengkapi pengetahuan polisi. Seorang polisi harus mempelajari tentang hukum dan hal-hal lain yang berkaitan tentang hukum. ${ }^{40}$

Menurut Satjipto Raharjo, polisi adalah hukum yang hidup. Melalui polisi ini janji-janji dan tujuan-tujuan hukum untuk mengamankan dan melindungi masyarakat menjadi kenyataan. Oleh karena itu dalam tugas melaksanakan penangkapan polisi tidak boleh keliru. Kemungkinan keliru menangkap orang dapat terjadi karena:

1. Penangkapan tersebut tidak ada alasannya yang syah menurut undang-undang;

2. Keliru menangkap, karena salah mengenai orangnya;

3. Keliru menangkap, karena hukum yang diterapkan ternyata tidak benar. ${ }^{41}$

Terhadap kekeliruan menangkap orang, polisi harus bertanggung- jawab untuk memikul risiko. Pertanggungjawaban yang harus diderita oleh polisi meliputi:

1. Pertanggungjawaban pidana;

2. Pertanggungjawaban perdata;

3. Pertanggungjawaban administratif dan disiplin. ${ }^{42}$

40Satjipto Rahardjo, Op. Cit., hal. 114.

41Sitompul. DPM, Op. Cit.,hal. 75. 
Kekeliruan menangkap orang yang dilakukan oleh oknum polisi karena adanya unsur sengaja atau unsur kelalaian dari petugas mempunyai dampak yang negatif bagi pribadi petugas tersebut maupun bagi kesatuan polisi. Dengan cepat masyarakat akan mengetahui masalah kekeliruan menangkap orang dari mulut ke mulut dan apabila sampai di ekspose dalam surat kabar akan mengakibatkan masalah kekeliruan itu lebih luas lagi diketahui oleh masyarakat.

Rasa malu dan sedih yang diderita oleh petugas polisi dan kepada polisi setempat yang menyuruh melakukan penangkapan itu juga dirasakan oleh anggota keluarganya.Rasa malu, sedih, dan kecewa yang diderita tidak mudah dihilangkan begitu saja dalam waktu yang singkat oleh petugas polisi maupun keluarganya.

1. Pertanggungjawaban Pidana

Anggota polisi yang melakukan kejahatan terhadap kemerdekaan seseorang (kesalahan dalam menangkap orang) diancam dengan hukuman pidana, karena masalah menangkap orang berhubungan erat dengan hak asasi manusia dan kebebasan bergerak seseorang maka terhadap kekeliruan menangkap orang diancam dengan hukuman Pasal 333 KUHP, Pasal 334 KUHP, Pasal 335 KUHP.

Pasal 333 ayat (1) KUHP:

(1) Barang siapa dengan sengaja menahan (merampas kemerdekaan) orang atau meneruskan tahan itu dengan melawan hak, dihukum penjara selamalamanya delapan tahun. 
(2) Jika perbuatan itu menyebabkan luka berat si tersalah dihukum penjara selama-lamanya sembilan tahun.

(3) Jika mengakibatkan mati, dikenakan pidana penjara paling lama dua belas tahun.

(4) Pidana yang ditentukan dalam pasal ini berlaku juga bagi orang yang dengan sengaja memberi tempat untuk perampasan kemerdekaan yang melawan hukum.

Andai kata petugas polisi tersebut keliru menangkap orang disebabkan ciri-ciri tubuh dari tersangka kebetulan sama dengan orang yang ditangkap, polisi tersebut tidak dapat diancam dengan hukuman Pasal 333 KUHP, karena unsur sengaja melakukan tindak pidana tidak terpenuhi.

Lain halnya jika petugas polisi tersebut dalam melakukan penangkapan ia bertindak serampangan, kurang hati-hati hingga lalai dan mengakibatkan kekeliruan menangkap, maka ia dapat diancam dengan Pasal 334 KUHP.

Pasal 334 KUHP:

(1) Barang siapa yang karena salahnya hingga orang jadi tertahan atau terus tertahan dengan melawan hak, dihukum kurungan selama-lamanya 3 bulan atau denda sebanyak-banyaknya Rp. 4500,-

(2) Jika karena perbuatan itu menyebabkan luka berat, si tersalah dihukum kurungan selama-lamanya 9 bulan.

(3) Jika perbuatan tersebut menyebabkan orangnya mati ia dihukum kurungan selam-lamanya 1 tahun.

Pasal 335 KUHP:

(1) Barang siapa secara melawan hukum memaksa orang lain supaya melakukan, tidak melakukan atau membiarkan sesuatu, dengan memakai kekerasan, sesuatu perbuatan lain maupun perlakuan yang tak 
menyenangkan, atau dengan memakai ancaman kekerasan, sesuatu perbuatan lain maupun perlakuan yang tak menyenangkan, baik terhadap orang itu sendiri maupun orang lain".

"Diancam dengan pidana penjara paling lama satu tahun atau denda paling banyak empat ribu lima ratus rupiah.

Pasal 335 KUHP dapat diterapkan bagi semua orang karena ada kata-kata "barang siapa" karena didalamnya termasuk polisi yang memaksa orang lain untuk mengakui suatu perbuatan yang melanggar hukum. Dalam hal ini, mengakui sebuah perbuatan yang tidak dilakukannya adalah kejahatan berbohong (apalagi di bawah sumpah di depan pengadilan).

Pasal 88 KUHP:

(1) "Dikatakan ada permufakatan jahat, apabila dua orang atau lebih telah sepakat akan melakukan kejahatan".

Dalam KUHP, dikenal istilah pemufakatan jahat. Apabila terpidana memang ditekan oleh polisi untuk mengakui perbuatan orang lain, maka perbuatan ini dapat dikategorikan sebagai pemufakatan jahat, karena polisi yang melakukan penyidikan tidak hanya 1 (satu) orang. Hal ini bukan sebuah kesalahan prosedur.

Sebuah pemufakatan jahat tidak dapat dilindungi oleh undang-undang. Jadi, apabila polisi yang melakukannya, secara otomatis (demi hukum), hak imunitas yang diberikan undang-undang bagi polisi tidak dapat diterapkan. Kalau mau diterapkan kepada jaksa dan hakim, maka kedua pihak ini pun 
harus bertanggungjawab secara pidana karena telah berbuat kesalahan, baik dalam menuntut maupun menjatuhkan putusan. Memang, kelemahan hukum Indonesia adalah tidak ada pengaturan yang jelas mengenai kesalahan menangkap ini secara khusus bagi polisi. Walaupun demikian, tetap saja, sebuah kejahatan harus dihukum.

Selanjutnya dalam Pasal 10 ayat (1), (2) dan ayat (3) PP No 3 Tahun 2003 tentang Pelaksanaan Teknis Institusional Peradilan Umum Bagi Anggota Polri dijelaskan bahwa :

(1) Anggota Polri yang dijadikan tersangka/terdakwa dapat diberhentikan sementara dari jabatan dinas Kepolisian Negara Republik Indonesia, sejak dilakukan proses penyidikan sampai adanya putusan pengadilan yang mempunyai kekuatan hukum tetap.

(2) Pemberhentian sementara dari jabatan dinas Polri dapat dilakukan secara langsung.

(3) Ketentuan tentang tata cara pelaksanaan pemberhentian sementara sebagaimana di maksud dalam ayat (2) diatur dengan Keputusan Kapolri.

Pemberhentian sementara dari dinas Polri sebagaimana dimaksud dalam Pasal 10 PP No 3 Tahun 2003, bertujuan untuk memudahkan proses penyidikan,sehingga proses penyidikan dapat berjalan sebagaimana yang diharapkan. Namun yang perlu dipahami bahwa Pasal 10 ayat (1) tersebut menggunakan kata dapat, yang menurut Kamus Besar Bahasa Indonesia, makna dapat diartikan bisa, mampu, sanggup, 
boleh, mungkin. Dengan demikian kata "dapat" bisa diartikan "dilakukan pemberhentian sementara dari dinas Kepolisian dan bisa tidak dilaksanakan pemberhentian sementara dari dinas Kepolisian", karena kata "dapat" tidak mengandung suatu kewajiban atau perintah. Pengertian ini sangat memungkinkan digunakan oleh pejabat yang berwenang terhadap anggota Polri yang dalam proses penyidikan, tidak dilakukan pemberhentian sementara. 43

2. Pertanggungjawaban Perdata

Di samping pertanggungjawaban sebagai pegawai pemerintah atau pejabat polisi, adanya pertanggungjawaban pribadi, yang dicantumkan dalam hukum perdata. Dalam Pasal 1365 KUH Perdata dinyatakan bahwa terhadap perbuatan yang melanggar hukum dan mengakibatkan kerugian bagi orang lain, maka orang yang melakukan perbuatan yang melanggar hukum itu diwajibkan untuk membayar ganti rugi.

Menurut hukum perdata melanggar hukum mengandung beberapa unsur yaitu:

1. Unsur Perbuatan;

2. Unsur Kesalahan;

3. Unsur Melawan Hukum, dan

4. Unsur Causalitas.

${ }^{43}$ Snai, "Proses Penyidikan Terhadap Anggota Polri" (On-line), tersedia di WWW: http://deswanarwanda.blogspot.com/2011/01/proses-penyidikanterhadap-anggota.html,(16Febuari 2011). 
Unsur perbuatan artinya, tindakan itu nyata-nyata terlihat ada akibatnya. Unsur kesalahan artinya mencakup kesalahan itu dibuat karena sengaja ataupun tidak sengaja (kelalaian).Unsur kerugian ada dua macam yaitu kerugian yang dapat dinilai dengan uang, dan unsur kerugian yang tidak dapat dinilai dengan uang. Unsur melawan hukum artnya, bukan saja melawan undang-undang yang ada tetapi juga meliputi urusan melawan norma-norma kepantasan yang ada atau keadilan. Unsur causalitas artinya, antara perbuatan yang dilakukan ada kerugian dan mempunyai hubungan sebab akibat dengan perbuayan tersebut.

Contoh dari unsur causalitas: seorang polisi melakukan penangkapan penjahat di toko, kemudian penjahat tersebut melarikan diri lewat kompleks pertokoan, dalam pengejaran polisi terpeleset jatuh dan tubuhnya menimpa kaca toko yang mahal hingga pecah. Polisi tersebut dapat dituntut Pasal 1366 KUH Perdata oleh pemilik toko, walaupun jatuhnya polisi tersebut tidak disengaja.

Selain Pasal 1365 dan Pasal 1366 KUH Perdata, masalah ganti rugi dapat dilihat dalam Pasal 9 Peraturan Pemerintah No. 27 Tahun 1983 tentang Pelaksanaan KUHAP sebagaimana dirubah dengan PP No. 58 Tahun 2010:

(1) Ganti kerugian berdasarkan alasan sebagaimana dimaksud dalam Pasal 77 huruf b dan Pasal 95 KUHAP, adalah imbalan serendah-rendahnya berjumlah $\mathrm{Rp}$. 5000. (Lima Ribu Rupiah) dan setinggi-tingginya Rp. 1.000.000.- (Satu Juta Rupiah). 
(2) Apabila penangkapan, penahanan dan tindakan lain sebagaimana dimaksud dalam Pasal 95 KUHAP mengakibatkan cacat sehingga tidak dapat melakukan pekerjaan atau mati, besarnya ganti kerugian setinggitingginya adalah Rp. 3.000.000.- (Tiga Juta Rupiah). Adapun pembayaran ganti kerugian tersebut dilakukan oleh Menteri Keuangan berdasarkan penetapan pengadilan (Pasal 11). Tata cara pembayaran ganti kerugian diatur lebih lanjut oleh Menteri Keuangan.

Sehubungan dengan Pasal 9 Peraturan Pemerintah No. 27 Tahun 1983 menunjuk kepada Pasal 77 huruf b KUHAP, adapun isi dari pasal tersebut adalah:

Pasal 77 huruf b KUHAP: Pengadilan negeri berwenang untuk memeriksa dan memutus sesuai dengan ketentuan yang diatur undang-undang ini tentang:

Huruf b: Ganti kerugian dan atau rehabilitasi bagi seorang yang perkara pidananya dihentikan pada tingkat penyidikan atau penuntutan.

Tuntutan ganti rugi dalam Pasal 77 huruf b KUHAP tersebut di atas ditujukan terhadap perkara-perkara yang tidak diajukan ke pengadilan dalam pengertian karena perkaranya dihentikan pada tingkat penyidikan dan perkara yang dihentikan dalam tingkat penuntutan oleh jaksa.

Pasal 95 KUHAP:

Tersangka, terdakwa atau terpidana berhak menuntut ganti kerugian karena ditangkap, ditahan, dituntut dan diadili atau dikenakan tindakan lain, tanpa alasan 
berdasarkan undang-undang atau karena kekeliruan mengenai orangnya atau hukum yang diterapkan.

Dari kedua pengertian pasal tersebut di atas Pasal 77 huruf b KUHAP dan Pasal 95 ayat (1) KUHAP ternyata ada dua pembedaan tuntutan ganti kerugian:

1. Tuntutan ganti kerugian terhadap perkara yang tidak diajukan ke pengadilan.

2. Tuntutan ganti kerugian terhadap perkara yang sudah dalam proses pengadilan.

Suatu kasus tindak pidana yang perkaranya tidak diajukan ke pengadilan oleh polisi, dan ternyata setelah itu ada tuntutan ganti rugi karena tindakan polisi yang melawan hukum (penangkapan dan penahanan, penyitaan tidak syah menurut undang-undang), maka tuntutan ganti rugi tersebut diperiksa dan diputuskan oleh praperadilan. Tetapi jika tuntutan ganti rugi itu diajukan setelah perkaranya dalam proses pengadilan, maka permintaan ganti rugi itu teknis, pelaksanaannya diperiksa dan diputus oleh hakim yang telah mengadili perkara tersebut.

Tata cara pembayaran ganti kerugian diatur lebih lanjut dengan Surat Keputusan Menteri Keuangan RI No. 983/KMK.01/1983. Dalam surat keputusan itu Ketua Pengadilan Negeri mempunyai peranan yang penting, karena arus pengurusan tuntutan ganti rugi tersebut permohonannya dilaksanakan atau melalui Ketua Pengadilan Negeri Setempat.

Pasal 5 Keputusan Menteri Keuangan RI. No. 983/KMK.01/1983 sebagai berikut: 
"Terhadap pejabat yang karena kesalahan, kealpaan atau kelalaiannya mengakibatkan negara harus membayar ganti kerugian, dapat dikenakan tindakan sesuai dengan peraturan yang berlaku".

Dari bunyi Pasal 5 SK. Menteri Keuangan tersebut ternyata pembayaran ganti rugi uang dilaksanakan oleh negara.Tetapi bagi pejabat polisi yang telah bersalah mengakibatkan negara harus membayar ganti rugi tersebut dapat dikenakan tindakan (hukuman disiplin atau tindakan administratif dan lain-lain).

Salah satu tugas polisi adalah menegakkan hukum tetapi bukan berarti ia kebal hukum. Polisi tetap dapat dihukum apabila ia melakukan kesalahan dalam melaksanakan tugasnya dan ancaman yang dapat menuntutnya antara lain adalah hukum perdata.

Apabila ditinjau dari sudut tersangka yang ditangkap, risiko penderitaan lebih besar lagi karena resiko yang harus ia derita dapat meliputi:

1. Kerugian yang bersifat materiil

2. Kerugian yang bersifat imateriil.

Kerugian yang bersifat materiil yang diderita oleh tersangka adalah merupakan kerugian-kerugian yang dapat diperhitungkan dengan uang. Sebagai contoh: Tersangka A ditangkap polisi, padahal A adalah seorang pedagang. Selama berada dalam penangkapan dan kemudian ditahan seharusnya ia dapat menyelesaikan bisnis dengannya dengan kemungkinan keuntungan-keuntungan yang sudah dapat dipastikan jika berhasil berjumlah jutaan rupiah. Tetapi karena ditangkap polisi, keuntungan itu hilang lenyap. 
Kerugian yang bersifat imateriil adalah kerugian-kerugian yang diderita oleh si tersangka meliputi hal-hal: perasaan takut, sedih, malu, sakit, kejutan psikis, dan lain-lain. Sebagai contoh: Tersangka B ditangkap polisi, sewaktu ia ditangkap seluruh tetangganya melihat dan berita tersebut dengan cepat menyebar luas keseluruh penjuru kota. Padahal sebelum peristiwa penangkapan itu semua orang tau bahwa bahwa B adalah warga yang baik dan terpandang. Akibat dari penangkapan itu B menderita rasa malu, sedih dan mengalami penderitaan psikis, termasuk juga seluruh keluarganya. Tentu saja malu dan tercemar nama baiknya itu tidak mudah dalam waktu singkat dipulihkan.

3. Pertanggungjawaban Administratif Dan Disiplin

Seorang polisi apabila melakukan tugas melampaui batas wewenang yang diberikan kepadanya tetapi tidak merugikan siapapun, tetapi melanggar ketentuan dinas harus bertanggungjawab atas perbuatannya tersebut. Mungkin perbuatan anggota polisi tersebut oleh masyarakat dianggap remeh dan tidak merugikan tetapi apabila dipandang dari segi perintah kedinasan atau peraturan dinas dilingkungan polisi tidak boleh dianggap ringan dan tidak boleh diabaikan begitu saja karena apabila diabaikan akan membahayakan dan merusak disiplin organisasi Polri. Setiap perbuatan petugas polisi yang melanggar ketentuan perintah dinas atau peraturan dinas dianggap melanggar ketentuan administratif dan oleh karenanya dikenakan sanksi administratif. 
Sanksi administratif dapat dijatuhkan dari yang paling ringan sampai yang paling berat, yaitu berupa:

1. Teguran;

2. Teguran tertulis;

3. Penundaan kenaikan gaji;

4. Penundaan pangkat;

5. Diberhentikan dengan hormat;

6. Dipecat.

Dalam hukuman disiplin mengenal tingkatan-tingkatan yaitu, tingkatan-tingkatan untuk yang berpangkat tamtama, bintara, maupun perwira, tiap tingkatan mempunyai ketentuan yang terkadang tidak sama. Hukuman disiplin perlu bagi anggota Polri, mengingat tugas dan sifat organisasinya. Dari uraian tersebut, ternyata tugas polisi itu mengandung risiko dan tanggungjawab yang tidak ringan, sebab dalam menangkap tersangka mengandung risiko berbagai macam yaitu polisi dapat terancam jiwanya, polisi dapat tidak disukai oleh masyarakat sekelilingnya, dan juga polisi dapat diancam dengan pertanggungjawaban pidana, perdata maupun tindakan administratif apabila ia keliru dalam menangkap orang.

Pada dasarnya tindak pidana yang dilakukan oleh anggota Polri, juga merupakan pelanggaran terhadap peraturan disiplin dan Kode Etik Profesi Polri, oleh karenanya Pasal 12 ayat (1) Peraturan Pemerintah Nomor 2 Tahun 2003 tentang Peraturan 
Disiplin Anggota Kepolisian Negara Republik Indonesia menegaskan bahwa:

(1) Penjatuhan hukuman disiplin tidak menghapus tuntutan pidana.

Pasal 12 ayat (1) di atas, dapat dipahami bahwa Anggota Polri yang disangka melakukan tindak pidana dan diselesaikan melalui mekanisme sidang disiplin (internal Polri), bukan berarti proses pidana telah selesai, namun dapat dilimpahkan kepada fungsi Reserse untuk dilakukan penyidikan lebih lanjut, sepanjang pihak korban menginginkannya, demikian pula dengan pelanggaran terhadap Peraturan Kapolri No. Pol. : 7 Tahun 2006 tentang Kode Etik Profesi Polri. Dalam konteks ini tergantung pada kebijakan Ankum dalam menyikapi permasalahan anggotanya.

Setiap pelanggaran hukum dan atau tindak pidana yang melibatkan atau pelaku perbuatan tindak pidana adalah anggota Polri, maka peranan Ankum sangat penting. Ankum menurut Pasal 1 angka 13 PP No. 2 Tahun 2003 tentang Peraturan Disiplin Anggota Polri adalah:

"Atasan yang karena jabatannya diberi kewenangan menjatuhkan hukum disiplin kepada bawahan yang dipimpinnya".

Pentingnya peranan Ankum ini, dapat menentukan anggotanya yang melakukan pelanggaran hukum termasuk tindak pidana, untuk dilakukan proses hukum baik untuk internal Polri, maupun proses peradilan umum. Setiap proses 
hukum harus sepengetahuan Ankum, karena Ankum mempunyai kewenangan penuh dan dianggap lebih mengetahui persoalan yang dihadapi masing-masing anggotanya. ${ }^{4}$

\section{E. Penutup}

Faktor penyebab kasus salah tangkap yang dilakukan oleh penyidik Polri sering terjadi yaitu yang pertama (1): dinamika kerja penyidik Polri yang begitu kompleks, hal ini dapat dilihat dari penyidik Polisi dihadapkan pada kasus-kasus yang harus disidik, mulai kasus konflik dalam rumah tangga hingga teror bom, baik yang bersifat kasus delik aduan maupun delik biasa. Kedua (2) yaitu kurangnya sumber daya manusia polisi dalam menentukan tingkat pelayanan dan penanganan kasus-kasus kejahatan karena Polisi yang dalam menangani perkara kurang menguasai ilmu pengetahuan tentang kepolisian dan ilmu-ilmu lain seperti sosiologi, kriminologi, psikologi, komputer, ekonomi, hukum dan lain-lain. Ketiga (3) proses penyidikan yang relatif sangat sulit.Keempat (4) Target atasan untuk segera menyelesaikan kasus tertentu dalam waktu cepat, dalam hal ini, pengabaian hak-hak tersangka sering menonjol.

Pertanggungjawaban pidana oleh penyidik Polri apabila terjadi kasus salah tangkap yaitu diterapkan ketentuan: menurut Pasal 335 ayat (1) KUHP, Pasal 1365 KUHPerdata, disiplin, dan kode etik (pemberhentian dengan tidak hormat). Upaya untuk mencegah dan penanggulangan yang dilakukan oleh penyidik Polri 
Pakuan Law Review Volume 4 Nomor 2, Juli-Desember 2018

e-ISSN:2614-485

agar kasus salah tangkap tidak terjadi lagi adalah sebagai berikut: mengedepankan prinsip perlindungan terhadap HAM, mengembangkan budaya sipil di Polri, mengefektifkan komisi etika dan disiplin di Polri, mengedepankan fungsi kontrol dari Mabes Polri, peningkatan sumber daya manusia Polri, peningkatan profesionalisme kerja anggota Polri, dan penerapan sanksi pidana yang tegas dalam peraturan perundang-undangan bagi anggota Polri yang melakukan pelanggaran. 


\section{DAFTAR PUSTAKA}

\section{A. Peraturan Perundang-Undangan}

Indonesia. Undang-Undang Dasar Negara Republik Indonesia Tahun 1945.(Lembaran Negara Republik Indonesia Tahun 1959 Nomor 75).

. Undang-Undang Nomor 2 Tahun 2002 tentang Kepolisian Negara Republik Indonesia.(Lembaran Negara Republik Indonesia Tahun 2002 Nomor 2.Tambahan Lembaran Negara Republik Indonesia Nomor 4168).

. Undang-Undang Nomor 8 Tahun 1981 tentang Hukum Acara Pidana.(Lembaran Negara Republik Indonesia Tahun 1981 Nomor 76. Tambahan Lembaran Negara Republik Indonesia Nomor 3209). . Kitab Undang-Undang Hukum Perdata

\section{B. Buku-Buku}

Abdussalam.Prospek Hukum Pidana Indonesia "Dalam Mewujudkan Rasa Keadilan Masyarakat".Jakarta: Restu Agung, 2006.

Al Marsudi Subandi.Penghantar Hukum Indonesia,Cetakan kedua Bogor: Akademia,2006.

.Pengantar Ilmu Hukum, Cetakan Kedua. Bogor: CV Insan Grafika, 2003.

Atmasasmita Romli.Perbandingan Hukum Pidana, Cetakan Pertama. Bandung: Mandar Maju, 2000.

Hamzah Andi."Hukum Acara Pidana Indonesia", edisi revisi. Jakarta: Sinar Grafika, 2001. 
Pakuan Law Review Volume 4

Nomor 2, Juli-Desember 2018

e-ISSN:2614-485

.Pengantar Hukum Acara Pidana Indonesia. Jakarta:Pradnya Paramita, 1984.

. Kekerasan Oleh Polisi, Jakarta: Sinar Grafika, 2004.

Harun M. Husein.Penyidikan dan Penuntutan Dalam Proses Pidana.Jakarta: Rineka Cipta, 1991.

Harahap M., Yahya.Pembahasan Perrmasalahan dan Penerapan KUHAP. Jakarta: Sinar Grafika, 2006.

Pembahasan Permasalahan dan Penerapan KUHAP, edisi kedua. Jakarta: Sinar Grafika, 2008.

Huda, Chairul. "Dari “Tiada pidana tanap Kesalahan' menuju kepada 'Tiada Pertanggungjawaban Pidana Tanpa Kesalahan"; Tinjauan Kritis Terhadap Teori PemisahanTindak Pidana dan Pertanggungjawaban Pidana. Jakarta: Pranada Media. 2006.

Hutabarat, Ramly.Persamaan Dihadapan Hukum (Equality Before The Law) Di Indonesia, Cetakan Pertama Jakarta: Ghalia Indonesia, 1985.

Loeqman, Loebby.Pra Peradilan Di Indonesia, Jakarta: Ghalia Indonesia, 1990.

Moeljatno. Asas-Asas Hukum Pidana, Jakarta : Rineka Cipta, 2002.

.Kitab Undang- Undang Pidana (KUHP), Jakarta: Bumi Aksara,Cet. 22, 2003.

Muladi.Pertanggungjawaban Korporasi Dalam Hukum Pidana, Bandung: Sekolah Tinggi Hukum Bandung, 1991.

Rajam Syamsul Bahri.Hukum Warganegara Dalam Hukum Acara Pidana, Dalam Panduan Bantuan Hukum di Indonesia pedoman Anda Memahami dan Menyelesaikan Masalah Hukum, editor: A. Zien dan Daniel Hutagalung, edisi pertama, Jakarta: Yayasan Lembaga Bantuan Hukum 
Indonesia dan Pusat Studi Hukum dan Kebijakan, 2006.

Rahardjo, Satjipto.Membangun Polisi Sipil, Jakarta: Kompas Media Nusantara, Cet kedua, 2007.

Reksodiputro Mardjono.Hak Asasi Manusia Dalam Sistem Peradilan Pidana KumpulanKarangan Buku Ketiga,Jakarta: Lembaga Kriminologi UI, 1994.

Sitompul.DPM.Polisi Dan Penangkapan, Bandung: Tarsito, Cetakan Pertama 1985.

Widhayanti, Erni.Hak-Hak Tersangka/Terdakwa Di Dalam KUHAP, Yogyakarta: liberty, 1988.

\section{Artikel}

Masdiana, Erlangga. "Polisi dan Fenomena Salah Tangkap". Jakarta : Gatra, 2008.

\section{Makalah dan Wawancara}

Seno Adji, Oemar. "Pengawasan dan Pengamatan Pelaksanaan Putusan Pengadilan", Makalah yang disampaikan pada lokakarya dan seminar mengenai hal-hal baru yang terkandung dalam KUHAP, Jakarta 7-9 Desember 1983.

\section{E. Internet}

Artasite. "Asas Hukum" (On-line), tersedia di WWW: http://artasite.blogspot.com/2010/11/asashukum.html, (03 Maret 2011).

Bambang Widodo Umar, "Korban Salah Tangkap Sering Kalah Melawan Polisi" (On-line), tersedia di WWW:http://www.suarakaryaonline.com/news.html?id=208687(16 Februari 2011). 
Bambang Widodo Umar, "Korban Salah Tangkap Sering Kalah Melawan Polisi" (On-line),tersedia di http://www.suarakarya-online .com/news.html?id=208687, (16 Februari 2011).

Elin Yunita Kristanti, DesyAfrianti, "13 Polisi Dihukum Minta Maaf Kepada Kemat Cs" (On-line), tersedia di WWW: http://nasional.vivanews.com/news/read/2434813_po lisi_dihukum_minta_maaf_pada_kemat_cs, (14 Februari 2011).

Haryanto, "Prinsip Pokok Negara Hukum", (On-line), tersedia di WWW:

haryantogago.blog.friendster.com200811prinsip//http: pokok-negara-hukum.(03 Maret 2011).

Nurochman Arazie, Sudah Gagal Kawin Jadi Korban Salah Tangkap juga" (On-line), tersedia di WWW: http://www.tempointeraktif.com/hg/hukum/2010/09 /29/brk,20100929281274,id.html, (17 Februari 2011).

Prinsip The Right Of Due Procces Of Law Dalam Proses Penyelidikan Dan Penyidikan" (On-line),tersedia di WWW: http://yudipriambudish.blogspot.com/2009/05/prinsi p-right-of-due-process-of-law.html, (03 Maret 2011).

Snai, "Proses Penyidikan Terhadap Anggota Polri" (On-line), tersedia di WWW: http://deswanarwanda.blogspot.com/2011/01/prosespenyidikan-terhadap-anggota.html, (16 Februari 2011).

\section{F. Wawancara}

Markus Jaya Zebua, Wawancara Via Telepon Dengan Penulis, Penyidik Reskrim Polresta Bogor, Sabtu, 12 Februari 2011. 